\title{
Amphidinolides and Iriomoteolides, Potent Anticancer Macrolides ${ }^{\dagger}$
}

\author{
Lluís Bosch, Víctor Cascales, Alejandro Castro-Alvarez, Cristian Marco, Elena Petit, \\ Anna M. Costa * and Jaume Vilarrasa \\ Secció de Química Orgànica, Facultat de Química, Universitat de Barcelona, 08028 Barcelona, Spain \\ * Correspondence: amcosta@ub.edu \\ + Presented at the 2nd Molecules Medicinal Chemistry Symposium (MMCS): Facing Novel Challenges in \\ Drug Discovery, Barcelona, Spain, 15-17 May 2019.
}

Published: 8 August 2019

Amphidinolides and iriomoteolides are complex macrolides isolated from cultured marine dinoflagellates of the genus Amphidinium sp. [1-4]. All of them are cytotoxic against several cancer cell lines, especially those with larger rings, with activities in the nanomolar range. Some years ago, we started a research program directed towards the synthesis and elucidation of the biological mechanism of action of several members of this family of natural products [5-9]. As part of this research effort, we have completed the total synthesis of some amphidinolides. Work is underway in our laboratories to complete the total synthesis of amphidinolide $\mathrm{B}_{2}$ and iriomoteolide $2 \mathrm{a}$.

Amphidinolide $\mathrm{K}$ and some of its stereoisomers and analogues were subjected to evaluation of the possible disruption of the $\alpha, \beta$-tubulin-microtubule and/or G-actin-F-actin equilibria. Preliminary studies suggest that amphidinolide $\mathrm{K}$ behaves as a stabilizer of F-actin in vitro. The interaction of several of these macrolides with actin has also been studied computationally in our laboratories.

\section{References}

1. Kobayashi, J. Amphidinolides and its related macrolides from marine dinoflagellates. J. Antibiot. 2008, 61, 271.

2. Kobayashi, J.; Kubota, T. Bioactive macrolides and polyketides from marine dinoflagellates of the genus amphidinium. J. Nat. Prod. 2007, 70, 451.

3. Kobayashi, J.; Tsuda, M. Amphidinolides, bioactive macrolides from symbiotic marine dinoflagellates. Nat. Prod. Rep. 2004, 21, 77.

4. Tsuda, M.; Kumagai, K.; Masuda, A.; Fukushi, E.; Kawabata, J. Iriomoteolide-2a, a Cytotoxic 23-membered macrolide from marine benthic dinoflagellate Amphidinium species. Heterocycles 2015, 91, 265.

5. Rodríguez-Escrich, C.; Urpí, F.; Vilarrasa, J. Stereocontrolled total synthesis of amphidinolide $\mathrm{X}$ via a silicontethered metathesis reaction. Org. Lett. 2008, 10, 5191.

6. Trigili, C.; Pera, B.; Barbazanges, M.; Cossy, J.; Meyer, C.; Pineda, O.; Rodríguez-Escrich, C.; Urpí, F.; Vilarrasa, J.; Díaz, J.F.; et al. Mechanism of action of the cytotoxic macrolides anphidinolide X and J. ChemBioChem 2011, 12, 1027.

7. Mola, L.; Olivella, A.; Urpí, F.; Vilarrasa, J. Synthesis of amphidinolide Y precursors. Tetrahedron Lett. 2014, 55, 900.

8. Sánchez, D.; Andreou, T.; Costa, A.M.; Meyer, K.G.; Williams, D.R.; Barasoain, I.; Díaz, J.F.; Lucena-Agell, D.; Vilarrasa, J. Total synthesis of amphidinolide K, a macrolide that stabilizes F-Actin. J. Org. Chem. 2015, 80, 8511.

9. Bosch, L.; Mola, L.; Petit, E.; Saladrigas, M.; Esteban, J.; Costa, A.M.; Vilarrasa, J. Formal total synthesis of amphidinolide E. J. Org. Chem. 2017, 82, 11021.

(c) 2019 by the authors. Licensee MDPI, Basel, Switzerland. This article is an open access article distributed under the terms and conditions of the Creative Commons Attribution (CC BY) license (http://creativecommons.org/licenses/by/4.0/). 